\title{
HAK CIPTA DAN KARYA SENI DI ERA DIGITAL
}

\author{
Fitri Murfianti \\ Fakultas Seni Rupa dan Desain \\ Institut Seni Indonesia (ISI) Surakarta \\ Email: fitri@isi-ska.ac.id
}

\begin{abstract}
In the past two decades, art and technology have increasingly become inseparable. Technology, in this case the internet, has produced a new era known as the digital era followed by the emergence of many problems, one of which is in the field of copyright. There are many cases of copyright infringement committed by art creators and the public both consciously and unconsciously due to lack of knowledge about copyright. Moreover, all the required information, now, is available on the Internet. This condition gives a big opportunity to plagiarize an art work. Through literature studies, this study focuses on the perspective of the limitations and exceptions of arts work copyright in the digital age and explains the concepts of regulation and protection. The results of this study will be very useful in developing the course content of Etika Profesi (Professional Ethics) and HAKI (IPR) in Visual Communication Design Study Program, the Faculty of Fine Arts and Design.
\end{abstract}

Keywords: Copyright, Artworks, Digital Era

\section{Pendahuluan}

Di era digital ini ketersediaan informasi sangat melimpah dan sangat mudah diperoleh, dipertukarkan, diakses, dan didistribusikan serta ditransmisikan kapan saja, dimana saja melalui mediayang menyediakan fasilitas internet. Karakteristik era digital seperti dipaparkan sebelumnya telah melahirkan suatu tantangan baru. Demikian juga dengan adanya revolusi teknologi dan digitalisasi konten juga telah memunculkan banyak kemungkinan dan tantangan baru. Salah satunya dirasakan pada bidang hak cipta. Bentuk nyata dari ciptaan tersebut bisa di bidang teknologi, ilmu pengetahuan, seni dan sastra (Riswandi dan Sumartiah,2006: 3).

Hak cipta adalah hak alam, dan menurut prinsip ini bersifat absolut, dan dilindungi haknya selama si pencipta masih hidup dan beberapa tahun setelahnya (Riswandi, 2009: 37). Hak cipta sebagai sebuah konsep hukum yang melindungi karya-karya dalam bidang seni, sastra, dan ilmu pengetahuan dengan memberikan hak eksklusif telah mengalami suatu permasalahan yang kompleks.
Jika melihat pada kompleksitas hak cipta di era digital, maka dapat diidentifikasikan beberapa tantangan dan permasalahan baru dalam bidang hak cipta. Para pengguna medium digital dapat bebas menentukan konten di medium tersebut. Selain itu, teknologi memungkinkan penyebaran informasi secara luas dan dapat dengan cepat diakses serta berbiaya murah yang langsung terhubung dengan sumbernya oleh pengguna tanpa melalui perantara. Melalui digitalisasi konten akan sangat memudahkan pelaku untuk melakukan manipulasi sehingga karya hasil manipulasi ini akan sangat sulit dibedakan dari karya aslinya.

Kehadiran internet telah mendorong keadaan ini semakin jauh dan berkembang pesat yang berdampak pada terbukanya akses informasi ini dan membuka peluang bagi siapapun untuk dapat mengakses informasi tersebut. Agar proses mengakses informasi yang ada di internet, di mana informasi tersebut mungkin saja dilindungi hak cipta, maka perlu dipahami secara menyeluruh dan utuh konsep hak cipta yang sifatnya memberikan hak eksklusif di satu sisi, namun di sisi lain memberikan 
pembatasan dan pengecualian hak cipta itu sendiri. Dengan memiliki pemahaman yang menyeluruh dan utuh ini dapat meminimalisir pelanggaran hak cipta di era digital dapat diminimalisir sedemikian rupa.

Berdasarkan latar belakang yang telah dipaparkan sebelumnya, maka rumusan masalah dalam penelitian pustaka ini yaitu: (1) Bagaimana konsep hak cipta karya seni yang sifatnya memberikan hak eksklusif di satu sisi, namun memberikan pembatasan dan pengecualian hak cipta itu sendiri di sisi lain?, dan (2) Bagaimana pengaturan dan proses perlindungan karya seni di era digital ini?

\section{B. Metodologi}

Artikel Perlindungan Hak Cipta dan Karya Seni di Era Digital ini termasuk dalam jenis penelitian hukum normatif dengan menggunakan metode riset pustaka atau kepustakaan, yaitu rangkaian kegiatan yang berkenaan dengan metode pengumpulan data pustaka, membaca, dan mencatat serta mengolah bahan penelitian. Penelitian ini memanfaatkan sumber literatur pustaka untuk memperoleh data penelitiannya. Jadi penelitian ini membatasi kegiatannya hanya 2 pada bahan-bahan koleksi perpustakaan baik online maupun offline, tanpa memerlukan riset lapangan. Prosedur kegiatan dan teknik penyajian hasil penelitian akan dipaparkan secara deskriptif.

\section{Hasil Dan Pembahasan}

\section{Pembatasan dan Pengecualian HAKI di Era Digital}

Konsep perlindungan hak cipta sebagai hak eksklusif tidak bersifat absolut. Hal ini diperjelas dengan adanya pembatasan dan pengecualian hak cipta yang mengindikasikan bahwa tidak semua ciptaan bisa diberi perlindungan hak cipta secara tetap. Pembatasan dan pengecualian hak cipta telah diatur dalam beberapa perjanjian internasional seperti
Konvensi Bern. Dalam konteks perlindungan hak cipta, ketika sebuah negara mengatur tentang pembatasan dan pengecualian hak cipta, maka hak cipta tidak bersifat monopoli absolut. Kepentingan pencipta senantiasa disesuaikan dengan kepentingan masyarakat umum.

Di beberapa negara, aturan hukum mengenai pembatasan dan pengecualian hak cipta diciptakan secara berbeda-beda. Sebagai contoh di Amerika, aturan ini disebut dengan fair use, sedang di Inggris disebut dengan fair dealing. Dan di negara civil law seperti Belanda tidak mengenal adanya konsep fair use maupun fair dealing. Akan tetapi Belanda mempunyai aturan pembatasan dan pengecualian hak cipta yang disebut De beperkingen van het auteursrecht atau pembatasan hak cipta.

Fair use merupakan doktrin hukum dimana seseorang diizinkan untuk melakukan reproduksi tanpa seizin dari pemegang hak cipta. Sebagai contoh di Amerika, dengan mengutip beberapa baris lagu, merangkum atau mengutip berita, mengadopsi beberapa paragraf dari artikel suatu berita untuk pendidikan serta mengutip artikel untuk penggunaan di dalam proses hukum.

Di negara lain, istilah fair use diubah menjadifair dealing, dimana sebuah pengecualian terbatas pada eksklusivitas kekayaan intelektual yang memungkinkan untuk mereproduksi atau studi pribadi terhadap material yang dilindungi serta dengan pengakuan yang tepat atau wajar.

Fair dealing meliputi reproduksi atas sastra, drama, musik atau karya seni untuk tujuan pendidikan, penelitian atau tujuan non komersial dimana tidak melanggar hak cipta yang telah diakui. Sebagai negara yang tergabung dalam WTO (World Trade Organization), Indonesia telah menyelaraskan segala perundang-undangan di bidang hak cipta dengan norma dan standar yang disepakati (Margono, 2010:5). Harmonisasi pembatasan dan pengecualian hak cipta dalam konvensi internasional dengan peraturan perundangan- 
undangan nasional adalah upaya penyesuaian berbagai macam konvensi internasional hak cipta yang menyangkut pembatasan dan pengecualian hak cipta dengan peraturan perundang-undangan nasional baik secara horizontal maupun vertikal (Riswadi, 2017: 12).

Adapun konvensi internasional hak cipta yang menyangkut pembatasan dan pengecualian hak cipta terdiri dari Konvensi Bern, Perjanjian TRIPs, WCT dan WPPT, sedangkan peraturan perundangan nasional dalam konteks ini adalah Undang-undang No. 28 Tahun 2014 tentang Hak Cipta. Konvensi Bern merupakan peraturan internasional pertama yang mengatur serta melindungi karyakarya cipta memiliki lebih banyak ketentuan dibandingkan dengan peraturan internasional lainnya. Tapi bukan berarti yang lainnya tidak penting. Dengan hadirnya peraturan internasional setelah Konvensi Bern, maka telah terjadi suatu penyesuaian satu dengan yang lain sehingga saling melengkapi.

Budi Agus Riswadi (2009) menjelaskan, pengaturan pembatasan dan pengecualian hak cipta telah mengalami pergeseran dalam beberapa hal. Pertama, pengaturan pembatasan dan pengecualian hak cipta yang diatur dalam konvensi tidak hanya pada wilayah konvensional namun sudah melingkupi pada wilayah digital. Kedua, pengaturan pembatasan dan pengecualian hak cipta telah mengalami perluasan objek hak cipta. Ketiga, pengaturan pembatasan dan pengecualian hak cipta telah memasuki metode three-step test yang mengalami pergeseran subjek hak cipta dari author ke copyright holder.

Pengaturan pembatasan dan pengecualian hak cipta mengalami evolusi seiring dengan perkembangan ilmu pengetahuan dan teknologi. Hal ini juga merupakan sebuah konsekuensi positif dari pengaturan hak cipta yang berbasis pada hasil olah pikir manusia tak terkecuali berkaitan dengan perkembangan teknologi informasi.

Untuk peraturan nasional sendiri,
Indonesia baru saja memberlakukan UU Hak Cipta No.28 Tahun 2014 sebagai pengganti UU Hak Cipta No. 19 Tahun 2002. UU Hak Cipta No. 28 Tahun 2014 merupakan upaya penyesuaian dari segala macam perubahan baik secara yuridis maupun sosiologis. Sesuai dengan Pasal 2 UU Hak Cipta No. 28 Tahun 2014 yang menjelaskan bahwa, sifat Hak Cipta merupakan hak eksklusif bagi si pencipta atau pemegang Hak Cipta untuk mengumumkan atau memperbanyak ciptaannya, yang timbul secara otomatis setelah suatu ciptaan dilahirkan tanpa mengurangi pembatasan menurut peraturan yang berlaku.

Selanjutnya, Budi Agus Riswadi (2009) menjelaskan bahwa penyesuaian hak cipta di Indonesia berkenaan dengan pembatasan dan pengecualian hak cipta tentu akan menyesuaikan dengan peraturan internasional hak cipta. Pertama, dalam UU No.28 Tahun 2014 penggunaan beberapa istilah dalam pembatasan dan pengecualian tidak sesuai dengan peraturan internasional. Perundangundangan nasional tidak menggunakan istilah "pengecualian" akan tetapi hanya menggunakan istilah "pembatasan" saja. Maka hal ini bisa berimplikasi terhadap masalah-masalah yang timbul di masa mendatang. Kedua, dalam perundang-undangan nasional, cangkupan perlindungan serta pembatasan dan pengecualian telah sesuai dengan peraturan internasional secara objek. Secara subjek, peraturan internasional mencantumkan subjek yang berbeda-beda. Semisal dalam Konvensi Bern dan WCT menggunakan subjek hak cipta dengan sebutan "author" atau penulis, "right holder" sebagai subjek hak cipta dalam perjanjian TRIPs, dan "performances" dan "producer of phonogram" sebagai subjek hak cipta dalam WPPT. Sedangkan dalam UU Hak Cipta No.28 Tahun 2014 mencantumkan semua yaitu "pencipta", "pemegang hak cipta", "produser rekaman suara", "pelaku pertunjukkan", serta "lembaga penyiaran". Pencantuman semua subjek di dalam UU Hak Cipta No.28 Tahun 
2014 merupakan upaya penyesuaian terhadap semua konvensi internasional sekaligus sebagai bentuk kepatuhan terhadap upaya ratifikasi atas semua konvensi tersebut.

\section{a. Metode Three-Step Test sebagai Metode Pembatasan}

Peraturan Hak Cipta di Indonesia telah jelas diatur di dalam UU Hak Cipta No.28 Tahun 2014 dan Indonesia merupakan negara yang turut serta dalam berbagai kegiatan serta perjanjian internasional. Di dalam peraturan international hak cipta, khususnya dalam Konvensi Bern, Perjanjian TRIPs, WCT dan WPPT, telah lama diatur mengenai three-step test sebagai metode pembatasan. Three-step test sendiri merupakan suatu klausa yang terdapat di dalam peraturan internasional yang berfungsi untuk menguji suatu pembatasan dan pengecualian hak cipta yang dapat diterapkan di negara-negara yang tergabung di dalam peraturan internasional tersebut. Di Indonesia sendiri, peraturan mengenai three-step test telah diatur mengenai pembatasan hak cipta sekaligus merupakan hasil pengujian itu sendiri. Three-step test terdiri dari tiga langkah pengujian yaitu, Pertama, suatu karya satra dan seni dapat diperbolehkan untuk direproduksi di suatu kondisi atau kasus-kasus tertentu. Kedua, selama reproduksi tidak bertentangan dengan eksploitasi atau penggunaan yang wajar dari sebuah karya, serta Ketiga, selama tidak merugikan kepentingan pencipta / pengarang. Semuanya diatur secara parsial dan keseluruhan di dalam pembatasan hak cipta di Indonesia. Pembatasan Hak Cipta dapat dilakukan selama tidak bertentangan dengan moral, agama, ketertiban umum, kesusilaan, pertahanan dan keamanan negara.

Dengan diaturnya three-step test di dalam UU Hak Cipta Indonesia, bukan berarti bahwa Indonesia telah sepenuhnya harmonis dengan peraturan hak cipta internasional. Terdapat dua jenis perbedaan antara pembatasan dan pengecualian hak cipta di dalam peraturan internasional apabila dilihat dari segi ruang lingkup perlindungan serta objek yang dilindungi, yakni secara konvensional dan lingkungan digital. Ruang lingkup serta objek secara konvensional diatur dalam Konvensi Bern dan Perjanjian TRIPs, karena keduanya belum mengatur adanya perlindungan di dalam lingkungan digital atau ciptaan yang dibuat secara digital. Sedangkan untuk WCT dan WPPT, keduanya telah mengatur mengenai ruang lingkup serta ciptaan yang dibuat secara digital.

\section{b. Technological Protection Measure sebagai Pembatasan Hak Cipta Digital}

Dalam Penjelasan Umum UndangUndang Nomor 28 Tahun 2014 tentang Hak Cipta, perkembangan teknologi informasi dan komunikasi telah menjadi salah satu variable, mengingat teknologi informasi dan komunikasi di satu sisi memiliki peran strategis dalam pengembangan hak cipta, tetapi di sisi lain juga menjadi alat untuk pelanggaran hukum di bidang ini.

Salah satu perkembangan teknologi informasi dan komunikasi yang meiliki peran strategis dalam pengembangan hak cipta yakni internet. Dengan adanya internet, setiap orang bisa secara bebas mengakses data melalui mesin pencari. Salah satu akses yang sering digunakan yakni mengunggah karya cipta. Seseorang dapat secara bebas untuk menggunakan karya cipta itu yang akhirnya dapat menimbulkan pelanggaran.

Dari kondisi demikian, dari sisi hukum, fenomena internet sangat jelas berpengaruh terhadap model pengaturan hukum di internet. Penerapan hukum saat ini pada kenyataannya masih banyak memiliki kelemahan. Beberapa kelemahan itu antara lain sangat dibatasi oleh yurisdiksi dan sangat bergantung dengan hal-hal yang sifatnya formal (Mertokusumo, 2000:87). Kelemahan yang dimiliki oleh hukum konvensional saat ini menunjukkan juga kompleksitas dari objek yang diatur 
(Riswadi, 2009:56). Kompleksitas pengaturan ini, melahirkan berbagai permasalahan hukum, salah satunya adalah hak cipta. Menurut Asril Sitompul, ada 2 (dua) kategori hak cipta di internet yakni Pertama, hak cipta atas isi (content) yang terdapat di media internet yang berupa hasil karya berbentuk informasi, tulisan, karangan, review, program atau bentuk lainnya yang sejenis. Kedua, hak cipta atas nama alamat situs web dan alamat surat elektronik atau email dari pelanggan jasa internet.

Lahirnya internet tanpa didasari mengubah pola perilaku manusia serta hubungannya antar manusia. Pola perilaku tersebut antara lain internet gambling, music download, digital image download dan internet copying. Internet copying merupakan tindakan memperbanyak informasi berupa tulisan atau artikel yang dilakukan baik secara legal maupun ilegal. Dengan pengertian ini, internet copying pada hakekatnya tidak selalu merupakan suatu tindakan yang dibenarkan, tetapi sangatlah mungkin merupakan tindakan melawan hukum.

Fenomena internet copying dapat dijadikan contoh pelanggaran hak cipta yang dilakukan dalam hal teknologi informasi dan komunikasi. Meskipun pada dasarnya tidak selalu diakhiri dengan tindakan komersialisasi, tetapi tetap merugikan si pencipta karena dapat dilakukan perubahan nama penulis dan isi (content) dari tulisan atau artikel. Menurut UU No.28 Tahun 2014 tentang Hak Cipta, internet copying termasuk dalam kategori penggandaan. Yaitu suatu proses, perbuatan atau cara menggandakan satu salinan ciptaan atau fonogram atau lebih dengan cara dan dalam bentuk apapun, secara permanen atau sementara. Untuk meminimalisir kerugian, teknologi berupa pencantuman label hak cipta pada setiap karya digital dapat dijadikan pilihan proteksi.

Menurut Suhono, dkk, bahwa kerangka pelabelan hak cipta pada data digital sebenarnya dapat dilakukan dengan menggunakan teknologi sebagai berikut : a. Header Marking, dengan memberikan keterangan atau informasi hak cipta pada header dari suatu data digital.

b. Visible Marking, dengan memberikan tanda hak cipta pada digital secara eksplisit.

c. Encryption, mengkodekan data digital ke dalam representasi lain yang berbeda dengan representasi aslinya dan memerlukan sebuah kunci dari pemegang hak cipta untuk mengembalikan ke representasi aslinya.

d. Copy Protection, memberikan proteksi pada data digital dengan membatasi atau dengan memberikan proteksi dengan sedemikian lupa sehingga data digital tersebut tidak dapat dipublikasikan.

Berkaitan dengan permasalahan internet copying, salah satu proteksi yang tepat untuk memberikan perlindungan adalah dengan teknologi Encryption. Metode Encryption dapat ditemukan dalam suatu teknologi yang disebut Technology Protection Measure, yang merupakan teknologi yang dapat digunakan untuk melindungi materi dari suatu hak cipta.

Technology Protection Measure merupakan sebuah perangkat lunak ataupun komponen yang digunakan oleh pemilik hak cipta untuk melindungi materi dari hak cipta, seperti misalnya menggunakan enkripsi kode software dan password. Technology Protection Measure diciptakan untuk mengamankan integritas, menjaga kerahasiaan, dan otentifikasi dari sebuah karya cipta yang berbentuk internet. Technology Protection Measure digunakan oleh pemilik hasil ciptaan intelektual untuk melindungi ciptaannya dari pelanggaran dan penggunakan yang tidak semestinya (dilansir dari Review of Technological Protection Measures Exceptions, Canberra, Australia: 2006, Page 8). Apabila memperhatikan karakteristik dan kegunaan Technology Protection Measure 
sebagai salah satu teknologi yang dapat memberikan perlindungan pada ciptaan. Maka hendaknya Technology Protection Measure dapat diterapkan dalam sebuah aturan agar dapat lebih menjamin perlindungan hukum.

Di Indonesia, pengaturan mengenai Technology Protection Measure sebagai sebuah teknologi yang dapat memberikan perlindungan terhadap ciptaan dapat dilihat di dalam UU No. 28 Tahun 2014 tentang Hak Cipta. Meskipun dalam Undang-undang Hak Cipta tersebut belum dijelaskan secara eksplisit mengenai metode dan penggunaannya, namun dapat dikualifikasikan kedalam pengaturan tentang sarana kontrol teknologinya. Sarana kontrol teknologi adalah setiap teknologi, perangkat atau komponen yang dirancang untuk mencegah atau membatasi tindakan yang tidak diizinkan pleh pencipta, pemegang hak cipta, pemilik hak terkait dan yang dilarang oleh perundangundangan.

Perlindungan melalui Technology Protection Measure dapat digunakan dengan cara menerapkan password dan metode kriptografi pada sebuah konten hak cipta. Salah satu metode kriptografi dalam Technology Protection Measure dapat ditemukan dalam jenis Access Control Technology Protection Measure. Kriptografi memungkinkan komunikasi informasi dengan cara menyamarkan, sehingga muatan isi materinya tersembunyi dari pihakpihak yang tidak sah untuk mengakses (Risher, 2000).

Bila pemegang hak cipta menerapkan Technology Protection Measure dengan metode ini, maka seseorang tidak dapat melakukan internet copying atau tindakan lain dengan maksud buruk, bahkan untuk kegiatan yang komersial. Sehingga hak eksklusif bagi pemegang hak cipta dapat lebih terjamin perlindungannya.

Pembatasan perlindungan hak cipta memiliki konsekuensi bila penggunaan, pengambilan, penggandaan dan pengubahan suatu ciptaan atau produk dapat dilakukan sesorang untuk kepentingan pendidikan, penelitian, penulisan karya ilmiah, keamanan serta penyelenggaraan pemerintah, legislatif dan peradilan. Penggunaan Technology Protection Measure yang bermaksud melindungi konten hak cipta melalui metode password atau metode kriptografi, akan menghambat kepentingan pengguna hak cipta yang memang benarbenar menggunakan konten hak cipta untuk kepentingan pendidikan atau kepentingan non komersial lainnya.

Technology Protection Measure memang dapat memberikan perlindungan kepada pihak pencipta atau pemegang hak cipta, namun mengurangi akses pihak user, sehingga menguntungkan pihak pencipta atau pemegang hak cipta, namun merugikan pihak user, terutama bila digunakan untuk kepentingan pendidikan, pengajaran ataupun penelitian.

\section{c. Creative Commom sebagai Alternatif Perlindungan Hak Cipta Digital}

Seperti dikutip dari situs resmi creativecommons.org, lisensi hak cipta Creative Commons dan alat-alatnya membentuk keseimbangan dalam pengaturan tradisional yang ada pada hukum hak cipta. Lisensi ini memberikan setiap orang, dari pencipta individu sampai dengan perusahaan dan lembaga besar, cara sederhana standar untuk memberikan izin hak cipta atas ciptaan kreatif mereka. Kombinasi dari Creative Commons merupakan kumpulan komunitas digital yang luas dan berkembang, kolam konten yang dapat disalin, didistribusikan, digubah, dan dibuat ciptaan turunannya, dan semua dalam batas-batas hukum hak cipta.

Seluruh lisensi Creative Commons memiliki banyak fitur penting yang serupa. Setiap lisensi membantu para pencipta tetap memegang hak cipta walau mengizinkan orang lain untuk menyalin, menyebarluaskan, dan menggunakan ciptaan mereka, paling tidak untuk kepentingan non komersial. Setiap lisensi 
Creative Commons juga menjamin para pencipta mendapatkan kredit yang pantas atas ciptaan mereka. Setiap lisensi Creative Commons dapat digunakan di seluruh dunia dan berlaku sepanjang masa berlaku hak cipta (karena mereka dibuat berdasarkan aturan hak cipta). Fitur tersebut merupakan titik pangkal lisensi, dan pemberi lisensi dapat memberikan izin tambahan saat memutuskan batasan lain untuk setiap orang yang menggunakan ciptaan mereka.

Di dalam konsep lisensi Creative Commons terdapat 6 (enam) variasi bentuk lisensi dan setiap bentuk memiliki akibat hukum baik bagi pencipta (lisensor) maupun pengguna (lisensee). Bentuk dari lisensi Creative Commons antara lain :

a)

Lisensi Atribusi / CC BY

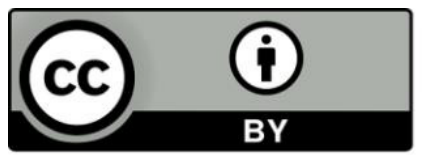

Lisensi ini mengizinkan setiap orang untuk menggubah, memperbaiki, dan membuat ciptaan turunan, bahkan untuk kepentingan komersial, selama mereka mencantumkan kredit kepada Pencipta atas ciptaan asli. Lisensi ini adalah lisensi yang paling bebas. Direkomendasikan untuk penyebarluasan secara maksimal dan penggunaan materi berlisensi.

b)

$$
\begin{aligned}
& \text { Lisensi Atribusi - Berbagi Serupa } \\
& \text { / CC BY-SA }
\end{aligned}
$$

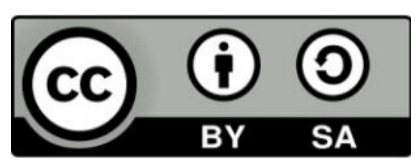

Lisensi ini mengizinkan setiap orang untuk menggubah, memperbaiki, dan membuat ciptaan turunan bahkan untuk kepentingan komersial, selama mereka mencantumkan kredit kepada Pencipta dan melisensikan ciptaan turunan di bawah syarat yang serupa. Lisensi ini seringkali disamakan dengan lisensi "copyleft" pada perangkat lunak bebas dan terbuka. Seluruh ciptaan turunan dari ciptaan Pencipta akan memiliki lisensi yang sama, sehingga setiap ciptaan turunan dapat digunakan untuk kepentingan komersial. Lisensi ini digunakan oleh Wikipedia, dan direkomendasikan untuk materi-materi yang berasal dari penghimpunan materi Wikipedia dan proyek dengan lisensi serupa.

c)

$$
\begin{aligned}
& \text { Lisensi Atribusi - Tanpa Turunan / } \\
& \text { CC BY-ND }
\end{aligned}
$$

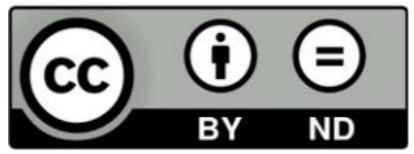

Lisensi ini memungkinkan orang lain menggunakan kembali karya untuk tujuan apa pun, termasuk secara komersial. Namun tidak dapat dibagikan dengan orang lain dalam bentuk yang disesuaikan, dan kredit harus diberikan kepada Pencipta.

d)

$$
\begin{aligned}
& \text { Lisensi Atribusi - Non Komersial } \\
& \text { / CC BY-NC }
\end{aligned}
$$

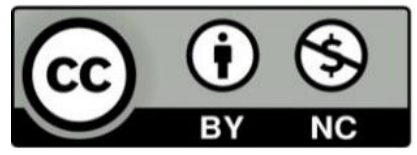

Lisensi ini mengizinkan setiap orang untuk menggubah, memperbaiki, dan membuat ciptaan turunan bukan untuk kepentingan komersial, dan walau mereka harus mencantumkan kredit kepada Pencipta dan tidak dapat memperoleh keuntungan komersial, mereka tidak harus melisensikan ciptaan turunan dengan syarat yang sama dengan ciptaan asli.

e)

$$
\begin{aligned}
& \text { Lisensi Atribusi - Non Komersial - } \\
& \text { Berbagi Serupa / CC BY-NC-SA }
\end{aligned}
$$

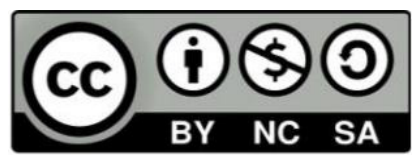

Lisensi ini mengizinkan setiap orang untuk menggubah, memperbaiki, dan membuat ciptaan turunan bukan untuk kepentingan komersial, selama mereka mencantumkan kredit kepada Pencipta dan melisensikan ciptaan 
turunan dengan syarat yang serupa dengan ciptaan asli.

f) Lisensi Atribusi - Non Komersial Tanpa Turunan / CC BY-NC-ND

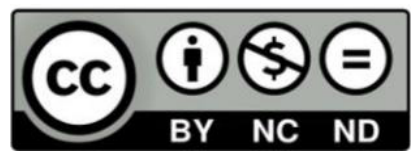

Lisensi ini adalah lisensi yang paling ketat dari enam lisensi utama, hanya mengizinkan orang lain untuk mengunduh ciptaan dan membaginya dengan orang lain selama mereka mencantumkan kredit kepada Pencipta, tetapi mereka tidak dapat mengubahnya dengan cara apapun atau menggunakannya untuk kepentingan komersial.

\section{Perlindungan HAKI terhadap Karya Seni di Era Digital}

\section{a. Perlindungan HAKI terhadap Karya Seni Tari di Era Digital}

Tari sebagai suatu cabang kesenian pada dasarnya substansi pokoknya merupakan gerak dan ritme, gerak dalam pandangan John Martin merupakan pengalaman fisik yang paling elementer dari kehidupan manusia. Gerak tidak hanya terdapat pada denyutan-denyutan di seluruh tubuh manusia untuk tetap dapat memungkinkan manusia hidup, tetapi gerak juga terdapat pada ekspresi dari segala emosionil manusia (Martin, 1965).

Karya cipta seni tari sebagai hasil kreatifitas manusia dengan akal budinya Tidak serta merta tercipta begitu saja, dengan tenaga dan biaya yang dikeluarkan, Pada prinsipnya juga membutuhkan suatu adanya perlindungan dan penghargaan terhadap karya cipta mereka. Secara umum, berdasarkan teori,terbagidalam 4 (empat) macam. (Harjowidigdo, 2005)

Pertama, Teori Reward, yang menyatakan bahwa kepada para penemu dan pencipta diberikan suatu penghargaan dan pengakuan.
Kedua, Teori Insentif, yang menyatakan bahwa insentif diberikan kepada para penemu dan pencipta yang telah berhasil melahirkan karya intelektualnya itu guna merangsang upaya atau kreatifitas menemukan dan mencipta lebih lanjut.

Ketiga, Teori Risk yang menyatakan bahwa pada dasarnya karya intelektual manusia itu bersifat rintisan, sehingga ada resiko oleh pihak lain untuk me-refers atau mengembangkan lebih lanjut dari karya intelektual tersebut.

- Keempat, Teori Public Benefit, atau Teori Economic Growth Stimulus, atau Teori More Things Will Happens, yang menyatakan bahwa karya intelektual manusia itu merupakan suatu alat untuk meraih dan mengembangkan ekonomi.

Perlindungan hukum yang telah ada ini dirasa cukup baik dengan adanya undangundang tentang hak cipta, namun terdapat beberapa kekurangan bahwa dalam undangundang tersebut kurang menjelaskan mengenai ekspresi budaya tradisional dan perlu adanya sosialisasi bagaimana seni tari juga mendapatkan perlindungan secara hak cipta.

Pemerintah Indonesia melalui UndangUndang No. 5 Tahun 2017 telah memberikan perlindungan terhadap seni tari tradisional yang dilakukan dengan cara membuat database terhadap kekayaan seni tari secara tersendiri. Kemudian bisa dishare ke internet agar semua orang tahu mengenai kesenian tari tradisional itu tersebut asalnya dari Indonesia, tentang siapa maestronya, siapa ahlinya, siapa guru yang bisa didatangi kalau mau belajar, dan sebagainya. (Atsar, 2007).

\section{b. Perlindungan HAKI terhadap Karya Seni Sinematografi di Era Digital}

Karya sinematografi atau yang lebih 
dikenal dengan istilah film, merupakan bentuk dari seni audio visual yang timbul dari hasil pemikiran seseorang atau intelektualitasnya. Ide yang timbul kemudian dikembangkan, diproduksi, dan akhirnya menghasilkan suatu karya nyata yang dapat dinikmati setiap orang. Karya sinematografi merupakan bagian dari objek perlindungan hak cipta, sebagaimana yang tercantum dalam Pasal 40 Undang-Undang Hak Cipta. Secara internasional perlindungan yang diberikan pada karya sinematografi pada awalnya tercantum dalam Konvensi Bern yang menyatakan bahwa ekspresi karya sastra dan seni dilindungi, yang di dalamnya mencakup pula karya sinematografi. Karya sinematografi sebagai bagian dari hak cipta mengalami perkembangan yang pesat, yang mana semakin tahun semakin mengalami peningkatan baik itu dari segi penonton ataupun sinematografi (Ni Made Rian Ayu, I Made Sarjana, 2018:4). Tetapi perkembangan ini rupanya tidak lantas menjadikan karya cipta dapat dilepaskan dengan adanya risiko yang membayangi.

Di Indonesia, karya sinematografi merupakan objek hak cipta yang cukup tinggi diedarkan dalam internet melalui situs streaming dan unduh gratis. Suatu karya yang didistribusikan dan ditransmisikan ke dalam internet dapat dikategorikan sebagai suatu dokumen elektronik. Dalam Pasal 25 UndangUndang ITE, menyatakan bahwa informasi elektronik maupun dokumen elektronik yang disusun menjadi karya intelektual, situs internet, dan karya intelektual yang ada di dalamnya dilindungi sebagai bagian dari HKI berdasarkan ketentuan Peraturan Perundang-undangan.

Proses tersebut nyaris tidak memerlukan perantara fisik, karena semua prosesnya terjadi secara otomatis dari film yang berbentuk data dan diunduh melalui perangkat yang terkoneksi internet. Praktik ini turut memperluas sirkulasi film yang ditawarkan, terlebih lagi penonton tidak perlu untuk mendaftar sebagai member untuk dapat mengunduh dan menontonnya atau secara anonim. Dengan kata lain, setiap orang yang mengunduh sulit untuk dimonitoring atau ditelusuri siapa saja yang mengunduh, film apa yang telah diunduh, serta film apa yang telah ditonton secara streaming. Penonton tidak perlu membayar tiket untuk menonton film seperti pada bioskop atau membayar untuk berlangganan konten yang disediakan situs maupun aplikasi resmi untuk menonton film. Penonton yang biasanya sering menonton di bioskop seolah dihadapkan pada pilihan terbatas, tetapi kini penonton lah yang leluasa untuk menentukan film mana dan apa yang akan ditonton secara daring atau diunduhnya.

Perbedaan biaya yang dibutuhkan untuk mengakses suatu karya sinematografi secara daring di internet menyebabkan aksi pembajakan karya sinematografi terus merebak. Meskipun masyarakat setuju dengan tindakan pemerintah untuk memerangi aksi pembajakan, namun masyarakat sesungguhnya juga banyak diuntungkan dengan adanya situs-situs bajakan ini. Di Indonesia ancaman terhadap konten pembajakan daring masih sangat tinggi, seperti pembajakan film. Menurut data terakhir yang dikeluarkan oleh United State Trade Representative (USTR) pada tahun 2018, Indonesia masuk dalam priority watch list. Artinya Indonesia merupakan negara dengan tingkat pelanggaran kekayaan intelektual yang cukup besar. Berdasar penjelasan yang dikeluarkan USTR, camcording atau rekaman secara ilegal merupakan sumber utama dari salinan film yang ada di internet, seperti filmfilm yang baru rilis di bioskop. Bahkan saat ini mudah untuk merekam secara sembunyisembunyi di bioskop untuk menghasilkan salinan digital yang bersih dengan audio yang baik yang dapat dengan cepat didistribusikan secara daring. Versi bajakan dari film sangat mungkin beredar saat film yang dibajak masih tayang di bioskop (United States Trade Representative, 2018:24-25).

Pemerintah juga melakukan pengawasan terhadap tindakan perekaman dengan menggunakan media apapun terhadap ciptaan 
dan produk hak terkait di tempat pertunjukan. Pemerintah melakukan himbauan kepada masyarakat melalui tempat pertunjukan (bioskop) yang umumnya akan diberikan peringatan untuk tidak melakukan perekaman atau pengambilan gambar atas suatu film yang sedang tayang. Selain itu perlindungan hukum bagi pencipta dilakukan dengan memberikan sanksi secara administratif kepada situs web yang melakukan pelanggaran hak cipta. Kerja sama dilakukan pemerintah dengan pihakpihak terkait yang dalam hal ini membidangi hukum dan komunikasi. Pihak yang turut andil adalah Kementerian Hukum dan Hak Asasi Manusia serta Kementerian Komunikasi dan Informatika. Berdasar Pasal 56 Undang-Undang Hak Cipta, Menteri yang menyelenggarakan urusan pemerintah di bidang telekomunikasi dan informatika dapat melakukan penutupan konten dan/atau akses pengguna yang melanggar hak cipta dalam sistem elektronik.

Pada tahun 2019 total sebanyak 348 bermuatan pelanggaran hak cipta diblokir oleh pemerintah (https://trustpositif.kominfo.go.id/ diakses 7 Agustus 2019). Namun hingga saat ini, masih terdapat beberapa situs penyedia layanan film bajakan yang masih dapat diakses, yaitu lk21.li, indoxxi.bz, dunia21.me, icinema3satu. net, grandxxi.tv, ganool.watch, nontonindoxxl. com, dan duniafilm21.com. Salah satu sampel situs penyedia layanan film bajakan adalah situs indoxxi.bz yang justru telah menduduki peringkat ke dua puluh dua sebagai situs yang paling banyak diakses di Indonesia dan menduduki peringkat ke 527 dunia. (https://www.similarweb.com/website/indoxxi. bz\#overview, diakses 2 Agustus 2019).

Menurut Ahmad M. Ramli, masalah pembajakan lebih disebabkan karena kurangnya kesadaran masyarakat akan pentingnya hak cipta sebagai perwujudan penghargaan bagi pencipta. Penjelasan kepada masyarakat akan hal ini tidaklah mudah dan harus dilihat secara komprehensif. Hukum hak cipta memberikan keseimbangan akan hak dan kewajiban, serta berdasarkan asas kesetaraan, persaingan yang sehat, dan kesamaan kesempatan. Sehingga sudah sepatutnya masing-masing pihak melakukan haknya sesuai dengan kedudukannya (Ramli, 2005: 78).

Dalam penegakan perlindungan hukum bagi pencipta aspek yang paling berpengaruh adalah pendekatan sosial kultural. Hal ini dapat meminimalisasi pelanggaran dan tindakan yang meresahkan dalam bidang hak cipta akibat penggunaan internet yang meningkat. Dengan adanya kesadaran sosial kultural akan perlunya internet dimanfaatkan secara positif dan otomatis akan dapat menekan pelanggaran hak cipta. Bahkan menurut Budi Agus Riswandi, dengan adanya kesadaran sosial kultural yang tinggi dalam pemanfaatan teknologi, maka hukum menjadi kurang begitu diperlukan. Hal ini karena masyarakat dengan sadar akan memanfaatkan teknologi sesuai dengan kebutuhan dengan tetap menjunjung sikap penghargaan kepada orang lain (Riswadi, 2009: 65).

Masuknya karya sinematografi sebagai salah satu objek yang mendapat perlindungan hak cipta merupakan langkah nyata adanya perlindungan hukum terhadap dunia perfilman, khususnya pada pencipta. Pemerintah telah melakukan upaya perlindungan hukum bagi pencipta karya sinematografi melalui peraturan dan undang-undang. Hal ini telah disesuaikan dengan kondisi digitalisasi pada era revolusi industri yang telah menggeser pola pelanggaran hak cipta dari konvensional menjadi elektronik melalui jaringan internet.

\section{c. Perlindungan HAKI terhadap Karya Seni Musik dan Lagu di Era Digital}

Pesatnya perkembangan kemajuan teknologi dewasa ini ternyata telah membuat tingginya maraknya pembajakan karya cipta lagu. Penggunaan sarana digital seolah-olah mempermudah dalam pendistribusian produk bajakan di bidang karya cipta. Dengan peralatan canggih seperti sekarang, proses penggandaan 
produk bajakan tidak lagi menjadi rumit. Pelaku pembajakan relatif mudah menggandakan produk karena tidak memerlukan ruang yang luas. Akibatnya sulit bagi penegak hukum untuk mendeteksinya.

Berdasarkan data yang dirilis oleh Asosiasi Industri Rekaman Indonesia (ASIRI), perkiraaan potensi kerugian bagi industri itu luar biasa besarnya. Begitu Juga dengan kerugian bagi pemasukan ke kas negara karena hilangnya potensi pemasukan pajak. Pada periode 19962007, ASIRI menyatakan jumlah peredaran produk rekaman lagu ilegal dalam format cakram optik diperkirakan mencapai 200 juta keping per tahun. Dari total peredaran produk bajakan itu, ASIRI memperkirakan potensi kerugian bagi industri rekaman selama kurun waktu sepuluh tahun terakhir mencapai Rp80 triliun. Sementara itu, akumulasi kehilangan pemasukan kas negara mencapai Rp8 triliun.

Sebagian besar pelanggaran hak cipta sebuah karya cipta lagu, terfokus terhadap pembajakan karya lagu melalui format media MP3. MP3 adalah sebuah singkatan dari Motion Picture Expert Group, Layer 3 yang merupakan format encoding suatu data audio yang bertujuan untuk mereduksi dan melakukan kompresi sejumlah data dalam audio tersebut, namun tetap memiliki kualitas audio sama dengan yang tidak mengalami kompresi (dilansir dari http:// www.wikipedia.org/wiki/mp3). Sebagai contoh, suatu data audio yang disimpan dalam format lain membutuhkan space sebesar 50 megabyte, sedangkan apabila menggunakan format MP3, space yang dibutuhkan hanya seperlimanya saja, yaitu sekitar 5 megabyte (Fall, 2004: 2).

Faktor ukuran data dari MP3 yang hanya membutuhkan space yang sedikit dari sebuah hardisk dan semakin maraknya diseminasi atau pertukaran data di internet yang dipacu semakin tingginya kecepatan transfer data di Internet, telah menyebabkan terjadi penyebaran data MP3 yang begitu pesat. Penyebaran yang begitu pesat ini menimbulkan suatu isu penting seputar MP3, yaitu aspek legalitas dari MP3 khususnya terkait dengan hak cipta.

Awal perkembangannya, kualitas suara musik atau lagu yang asli berbeda dengan kualitas lagu atau musik yang hasil bajakan. Namun dengan adanya teknologi konversi digital seperti adanya MP3, penurunan kualitas suara pada produk bajakan bisa diminimalisir, bahkan kualitas suara produk bajakan setara dengan kualitas suara pada CD orisinal (dilansir dari www.kompas.com/ kompas-cetak/0211/05/ dikbud/pemb30.htm, diakses 3 Agustus 2019). Selain itu harga sebuah keping MP3 illegal atau bajakan jauh lebih murah dari harga keping CD orisinal. Sebagai perbandingan, harga suatu keping MP3 illegal yang mampu memuat lebih dari seratus lagu berkisar lima ribu rupiah hingga sepuluh ribu rupiah, dibandingkan dengan MP3 bajakan yang beredar dengan harga lima ribu rupiah perkeping. Kedua faktor ini lah yang menyebabkan pembajakan MP3 di Indonesia semakin marak. (dilansir dari www.kompas. com/kompas-cetak/ 0605/15/Jabar/2080.htm, diakses 3 Agustus 2019).

Untuk menekan laju pembajakan dan atau peredaran MP3 bajakan di Indonesia perlu adanya law enforcement yang kuat dan tegas oleh aparat penegak hukum, Salah satunya melalui perlindungan terhadap Hak Kekayaan Intelektual. Perlindungan terhadap MP3 dalam sudut pandang hukum mengenai hak kekayaan intelektual khususnya hak cipta dapat kembali dipandang dari dua sisi yaitu form dan substance-nya. Dari sisi form-nya perlindungan hak cipta ditujukan pada MP3 sebagai software, sehingga MP3 memenuhi unsur sebagai Program Komputer sebagaimana dimaksud dalam Undang-Undang Hak Cipta.

Pengalihwujudan suatu karya cipta untuk tujuan komersil yang dilindungi oleh hak cipta harus berdasarkan izin dari Pencipta atau Pemegang Hak Cipta, sehingga apabila proses pengalihwujudan lagu atau musik menjadi lagu atau musik digital tanpa seizin dari Pencipta 
atau Pemegang Hak Cipta, hasil konversi tersebut dianggap telah melanggar hak cipta, hal ini disebabkan, proses pengalihwujudan atau konversi dari suatu karya cipta sudah merupakan proses perbanyakan dari karya cipta itu sendiri.

Hak Cipta merupakan hak eksklusif bagi Pencipta atau Pemegang Hak Cipta untuk mengumumkan atau memperbanyak Ciptaannya, yang timbul secara otomatis setelah suatu ciptaan dilahirkan tanpa mengurangi pembatasan menurut peraturan perundangundangan yang berlaku. Dengan demikian, apabila pengalihwujudan yang menyebabkan adanya perbanyakan terhadap suatu ciptaan tanpa izin dari pencipta atau pemegang hak cipta, tindakan tersebut dapat memenuhi unsur tindak pidana sebagaimana diatur dalam UUHC.

Meskipun MP3 tidak bisa dilindungi dengan Hak Paten, MP3 baik secara form maupun secara substansinya telah mendapat perlindungan hukum yaitu dengan adanya perlindungan terhadap hak cipta dari ciptaan MP3 tersebut. Permasalahan terkait MP3 illegal di Indonesia yang lebih banyak terjadi adalah pengalihwujudan musik dan lagu yang menyebabkan terjadinya perbanyakan ciptaan tanpa seizin pencipta atau pemegang hak cipta. Sedangkan permasalahan hak cipta terkait form dari software MP3 itu sendiri tidak banyak terjadi, hal ini antara lain disebabkan software MP3 memang dilisensikan sebagai free software yang artinya diperbolehkan untuk didistribusikan atau di salinkan secara gratis.

\section{d. Perlindungan HAKI terhadap Karya Fotografi di Era Digital}

Konsep hak cipta di Indonesia tanpa didaftarkan pun tetap dilindungi berbeda dengan merek, paten dan desain industri. Fotografi, masuk dalam kategori hak cipta (Pasal 40 UU 28 tahun 2014) yang oleh karenanya mendapatkan perlindungan secara otomatis sekalipun tak pernah didaftarkan. Berbeda dengan sistem di Amerika Serikat (AS) yang perlu pendaftaran untuk mendapatkan „,copy right', agar atas setiap ciptaan yang dikomersilkan oleh bukan penciptanya memperoleh nilai kompensasi yang lebih besar ketimbang ciptaan yang tak memiliki copy right.

Bentuk penggandaan dari suatu karya fotografi, dapat juga berbentuk duplikasi suatu foto dalam bentuk lukisan. Praktik demikian juga dapat dikategorikan sebagai pelanggaran hak cipta atas karya fotografi. Foto (atau gambar) termasuk karya yang secara otomatis akan dilindungi hak cipta begitu terwujud. Hal ini mengacu pada Pasal 12 Ayat 1 UndangUndang Hak Cipta (UUHC). Hak cipta memberi sejumlah hak ekslusif kepada pencipta gambar untuk melaksanakan perbanyakan, perubahan, dan melarang orang lain melaksanakan tindakantindakan tersebut tanpa seizinnya. Dengan kata lain, jika kamu menggunakan foto atau gambar dari internet untuk menghiasi konten blog atau yang lainnya tanpa seizin pemegang hak cipta, aktivitas tersebut dapat digolongkan sebagai pelanggaran hak cipta. Terlebih jika kamu melakukan modifikasi gambar tersebut. Ancamannya bisa berupa pidana atau dalam bentuk denda.

Meski begitu, Undang-Undang Hak Cipta juga mengatur pembatasan hak eksklusifpencipta. Tujuannya untuk memberikan keseimbangan antara perlindungan hukum kepada pemilik hak cipta sekaligus memberikan manfaat kepada masyarakat. Beberapa pembatasan tersebut di antaranya adalah untuk kepentingan pendidikan, penelitian, penulisan karya ilmiah, penyusunan laporan, penulisan kritik, atau tinjauan suatu masalah. Jadi, selama dilakukan terbatas untuk aktivitas yang bersifat nonkomersial, tidak merugikan kepentingan yang wajar dari pencipta, mencantumkan sumber, maka tidak akan dianggap sebagai pelanggaran hak cipta.

Agar terhindar dari kasus penyalahgunaan hak cipta, pengguna perlu membekali diri dengan pengetahuan tentang hak cipta foto di ranah digital. Bahkan, foto dengan lisensi Creative Commons, yang selama ini dianggap "aman" 
untuk digunakan secara bebas, ternyata terdiri dari beberapa kategori yang tidak semuanya bisa kamu gunakan dan bagikan sembarangan.

Sekarang telah ada lebih dari 227 juta foto berlisensi CC yang tersedia di ranah digital. Sebanyak tiga puluh persen di antaranya bisa digunakan untuk keperluan komersial. Di beberapa situs berikut ini, pengguna bisa menemukan banyak foto atau gambar berlisensi $\mathrm{CC}$ :

$\cdot$ Wikimedia Commons
- Flickr: Creative Commons
- Pexels
- Unsplash
- Pixabay
- Max Pixel

Dengan mengetahui lisensi foto digital, pengguna bisa menghindari risiko terjadinya pelanggaran hak cipta.

\section{e. Perlindungan HAKI terhadap Karya Desain Intellectual Property di Era Digital}

Pencurian, penjiplakan dan pembajakan karya desain semakin sering dilakukan di beberapa tahun belakangan ini. Pelakunya sendiri, entah mengapa seakan punya keberanian amat besar dengan men-discredit desainer aslinya. Bahkan, pelaku dari kejadian-kejadian menyedihkan ini bukan hanya dari desainer ke desainer lain, namun sering juga dilakukan perusahaan-perusahaan besar dalam rangka meraup keuntungan secara cuma-cuma (tanpa meng-hire desainer itu atau membayar atas hak karyanya).

Hak cipta otomatis muncul saat karya itu dibuat. Desainer bahkan tidak perlu mendaftarkan haknya di mana-mana supaya hak itu diakui.
Cukup wujudkan karyanya secara nyata. Konsekuensinya, ide tidak dapat dilindungi oleh hak cipta. Kalau ada yang menjiplak sebuah ide, desainer tidak bisa menggunakan hak cipta untuk melawan si penjiplak. Yang terpenting, selalu waspada dalam berbagi ide dan selalu wujudkan ide dalam sebuah bentuk nyata supaya hak ciptanya muncul, minimal dalam bentuk sketsa atau tulisan.

Pemerintah melalui Dirjen Kekayaan Intelektual memfasilitasi pencatatan hak cipta, sehingga desainer bisa memiliki surat „sakti ${ }^{\text {ie }}$ yang menyatakan bahwa desainer tersebut adalah pemegang hak cipta yang sah dari suatu karya cipta tertentu. Tapi, meskipun desainer belum mencatatkan hak ciptanya, mereka tetap berhak untuk menegur, menggugat, dan menuntut orang-orang yang menyalahi hak ciptanya. Desainer bisa minta mereka untuk menghentikan kegiatan pelanggaran mereka, atau mengajak kerja sama resmi supaya bisa menikmati keuntungannya juga. Jika mereka tidak mengindahkan teguran, desainer bisa menempuh jalur hukum, baik perdata maupun pidana. Untuk media sosial, kita bisa report posting-an mereka yang memuat karya kita dengan alasan pelanggaran hak kekayaan intelektual. Sayangnya tidak semua media sosial memfasilitasi pelaporan ini.

Tuangkan ide dalam suatu wujud yang nyata. Bubuhkan nama, tahun, dan tempat pembuatan pada karya cipta, supaya jelas siapa pemegang hak ciptanya, kapan dan di mana karya ini dibuat. Kalau sedang ada uangnya, catatkan hak cipta karya desain di Direktorat Jenderal Kekayaan Intelektual. Masa berlaku hak cipta berbeda-beda, tergantung dari jenis karya ciptanya. Misalnya untuk buku, gambar, dan musik, hak cipta berlaku hingga 70 tahun setelah penciptanya wafat. Sedangkan untuk, misalnya, fotografi dan film, hak cipta berlaku selama 50 tahun sejak pengumuman karya. Pengumuman adalah pembacaan, penyiaran, pameran, suatu ciptaan dengan menggunakan alat apapun baik elektronik/non-elektronik atau melakukan dengan 
cara apapun sehingga suatu ciptaan dapat dibaca, didengar, atau dilihat orang lain.

Dikutip dari ulasan seorang desainer, Tara Honor (2012) di situs business.tutsplus.com, dalam industri apa pun, akan selalu menghadapi risiko ketika sebuah kerja keras yang dibangun dalam membuat sebuah karya desain tibatiba dicuri dan digunakan tanpa mendapat kompensasi apapun. Memang hal tersebut merupakan sebuah risiko bisnis, tetapi dengan sedikit pendidikan dan perencanaan yang matang, hal tersebut dapat dihindari dengan melindungi karya desain Intellectual Property (IP) yang diciptakan oleh para perancang atau desainer sehingga memiliki peluang yang jauh lebih baik untuk menghindari pencurian IP.

\section{Kesimpulan}

Meninjau pada pandangan para sarjana hukum (doktrin) yang berkembang, maka dalam hukum ditemukan sebuah pandangan kewajaran penggunaan atau fair use yang dapat diartikan sebagai perbuatan yang tidak dianggap sebagai pelanggaran, dengan syarat penggunaan karya cipta dilakukan secara wajar yang tidak merugikan secara ekonomis dan moral kepada si pencipta karya. Hal ini dapat ditemukan dalam UU Hak Cipta No.28 Tahun 2014 Tentang Hak Cipta yang menjelaskan bahwa perbuatan tidak dianggap sebagai pelanggaran Hak Cipta, apabila penggunaan karya cipta orang lain, digunakan untuk kepentingan pendidikan, penelitian, penulisan karya ilmiah, penyusunan laporan, penulisan kritik, atau pembuatan salinan cadangan program komputer (pemilik), yang hanya untuk dipergunakan sendiri, atau dengan tidak merugikan kepentingan yang wajar dari si pencipta.

Apabila meninjau pada hukum yang berlaku di Amerika Serikat sebagai perbandingan dan tolak ukur bagi hukum sebagian besar negara-negara, maka US Copyright Act telah memberikan ukuran yang cukup jelas, yang dapat dijadikan sebagai faktor penentu untuk menilai bahwa, suatu perbuatan tidak dapat dikatakan sebagai pelanggaran Hak Cipta.

Penggunaan karya cipta yang memiliki tujuan untuk kegiatan non-komersial atau tujuan pendidikan, selain memiliki sifat karya cipta, jumlah karya cipta dan substansi karya cipta yang digunakan, harus memiliki tingkat kewajaran (proporsional), yang tidak berakibat kerugian besar terhadap potensi pasar karya cipta atau berakibat kerugian besar terhadap menurunnya nilai jual dari karya cipta tersebut. Pandangan kewajaran terhadap penggunaan karya cipta, (fair use) yang telah berkembang di sebagian besar negara telah memberikan kebebasan penggunaan dan perbanyakan secara terbatas kepada para perseorangan, dengan salah satu syarat yakni non-komersial.

Perlu diketahui bahwa perlindungan terhadap Hak Cipta tidak terbatas pada karya seni yang telah diproduksi dan dipasarkan secara meluas, tetapi perlindungan Hak Cipta juga meliputi seluruh karya (foto, musik, video, aplikasi, software hingga e-book) yang telah kita ciptakan sendiri, tanpa perlu memproduksi dan memasarkan secara masal. Hal ini sesuai dengan Pasal 2 UU Hak Cipta No.28 Ta h u n 2014 yang menjelaskan bahwa, sifat Hak Cipta merupakan hak eksklusif bagi si pencipta atau pemegang Hak Cipta untuk mengumumkan atau memperbanyak ciptaannya, yang timbul secara otomatis setelah suatu ciptaan dilahirkan tanpa mengurangi pembatasan menurut peraturan yang berlaku.

\section{Daftar Pustaka :}

Harjowidigdo, Rooseno. 2005. Perjanjian Lisensi HakCipta Musik dalam Pembuatan Rekaman. Jakarta: Perum Percetakan Negara Republik Indonesia

Martin, John. 1965. The Modern Dance. New York: Dance Horizons, Inc, Margono, Suyud. 2010. Aspek Hukum Komersialisasi Aset Intelektual. Bandung: 
Nuansa Aulia Mertokusumo, Sudikno. 2000. Hukum Acara Perdata Indonesia. Yogyakarta: Liberty

Ramli, Ahmad M. 2005. Film Independen dalam Perspektif Hukum Hak Cipta dan Hukum Perfilman Indonesia. Bandung: Ghalia Indonesia.

Riswandi, Budi Agus. Sumartiah, Siti. 2006. Masalah - Masalah HAKI Kontemporer. Yogyakarta: Gitanagari

Riswandi, Budi Agus. 2009. Hak Cipta di Internet: Aspek Hukum dan Permasalahannya di Indonesia. Yogyakarta: FH UII Press

Riswandi, Budi Agus. 2017. Pembatasan dan Pengecualian Hak Cipta di Era Digital. Yogyakarta: Citra Aditya Bakti

\section{Jurnal :}

Abdul Atsar, 2007, "Perlindungan Hukum Terhadap Pengetahuan Dan Ekspresi Budaya Tradisional Untuk Meningkatkan Kesejahteraan Masyarakat Ditinjau Dari Undang-Undang No. 5 Tahun 2017 Tentang Pemajuan Kebudayaan Dan Undang-Undang No. 28 Tahun 2014 Tentang Hak Cipta”, Jurnal Law Reform, Volume 13, Nomor 2, Fakultas Hukum Universitas Diponegoro

C, Risher. 2000. Tecnological Protection Measures (Anti Circumvention Devices) and their Relation Exceptions to Copyright in the Electronic Environment. Paper presented to the IPA Copyright Forum, Frankfurt Book Fair, 20 October 2000

Ni Made Rian Ayu Sumardani dan I Made Sarjana. 2018. "Perlindungan Hukum Terhadap Pencipta Karya Sinematografi Terkait Pembajakan Film Pada Situs Online". Jurnal Kertha Semaya. Vol. 6,
No. 3, Mei 2018. Denpasar: Universitas Udayana.

Review of Technological Protection Measures Exceptions, Canberra, Australia:2006

\section{Peraturan Perundang-Undangan:}

Undang-Undang Nomor 28 Tahun 2014 tentang Hak Cipta

\section{Website:}

http://www.creativecommons.org/

http://www.en.wikipedia.org/

\section{Artikel Internet :}

https://business.tutsplus.com/id/articles/how-toprotect-your-intellectual-property-from-theftas-a-freelancer

https://www.similarweb.com/website/indoxxi. bz\#overview

https://www.www.kompas.com/ kompascetak/0211/05/dikbud/pemb30.htm, diakses 3 Agustus 2019

https://www.www.kompas.com/kompas-cetak/ 0605/15/Jabar/2080.htm, diakses 3 Agustus 2019

https://ustr.gov/sites/default/files/files/Press/ Reports/2018\%20Special\%20301.pdf

United States Trade Representative. 2018. Diakses 2 Agustus 2019 